\title{
Analisis Pemidanaan Terhadap Tindak Pidana Pertambangan Batubara Tanpa Izin Usaha Pertambangan Studi Kasus Di Kutai
}

\author{
Victoria Sherly Endrico Putri \\ Hukum Ekonomi, Fakultas Hukum, Universitas Indonesia \\ Email: Victoria.sherly@ui.ac.id
}

\begin{abstract}
The development of mining crimes without mining business licenses at this time still occurs a lot, even though it has been regulated in Law Number 4 of 2009 concerning Mineral and Coal Mining, but in reality, convictions against perpetrators of mining business crimes without permits still deviate from Law Number 4 of 2009 concerning Mineral and Coal Mining, and not a few also the perpetrators of mining business without permission are given a light punishment not in accordance with the existing regulations even exempt. If this is kept on continuously, then mining business activities without permits will become more widespread and this will greatly harm the country and damage the environment. As for that being a problem formulation in the writing of this are how the mechanism of mining business activities in the mining of PT Utama Kawan Energi and whether the punishment in Case Decision Number 153 K / PID.SUS / 2016 has been in accordance with Law Number 4 of 2009 concerning Minerals and Coal Mining. And in this paper, using normative legal research methods (literature) to get the results of research on matters that are the problem in this writing, namely PT Utama Kawan Energi in conducting mining business activities not in accordance with what is regulated in Law Number 4 In 2009 about Minerals and Coal and the Judges even though they had punished him according to the laws and regulations, however, in imposing judgments the judges gave very light punishments, it should be based on the objective theory of absolute punishment, the Judges should give maximum punishment because what the defendant caused was very large.
\end{abstract}

Keyword: Mining Law, Criminal Acts In Mining Business Without Permission, Illegal Mining Punishment.

Abstrak. Perkembangan tindak pidana pertambangan tanpa izin usaha pertambangan pada masa ini masih saja banyak terjadi, meskipun sudah di ada pengaturannya di dalam Undang-Undang No 4 Tahun 2009 tentang Pertambangan Mineral dan Batu Bara, namun di dalam kenyataannya, pemidanaan terhadap pelaku tindak pidana usaha pertambangan tanpa izin masih menyimpang dari Undang-Undang No 4 Tahun 2009 tentang Pertambangan Mineral dan Batu Bara, dan tidak sedikit juga para pelaku kegiatan usaha pertambangan tanpa izin diberikan hukuman yang ringan serta tidak sesuai dengan peraturan yang ada bahkan sampai dibebaskan. Jika hal ini tetap di diamkan terus menerus, maka kegiatan usaha pertambangan tanpa izin akan semakin marak dan hal tersebut akan sangat merugikan negara dan merusak lingkungan. Adapun yang menjadi rumusan permasalahan dalam penulisan ini adalah bagaimana mekanisme kegiatan usaha pertambangan dalam pertambangan PT Utama Kawan Energi dan apakah pemidanaan dalam Putusan Perkara Nomor 153 K/PID.SUS/2016 penulisan ini, menggunakan metode penelitian hukum normatif (kepustakaan) untuk mendapatkan hasil penelitian tentang hal yang menjadi permasalahan dalam penulisan ini, yaitu PT Utama Kawan Energi dalam melakukan kegiatan usaha pertambangan tidak sesuai dengan apa yang di atur dalam Undang-Undang Nomor 4 Tahun 2009 tentang Mineral dan Batu Bara dan Majelis Hakim meski telah menjatuhkan hukuman sesuai dengan peraturan perundang-undangan. Namun, dalam menjatuhkan hukuman majelis hakim memberikan hukuman yang sangat ringan, seharusnya berdasarkan teori tujuan pemidanaan absolute, Majelis Hakim seharusnya memberikan hukuman yang maksimal karena kerugian yang ditimbulkan terdakwa sangat besar.

Kata Kunci: Hukum Pertambangan, Tindak Pidana Usaha Pertambangan Tanpa Izin, Pemidanaan Illegal Mining

\section{PENDAHULUAN}

Pertambangan merupakan sebuah industri yang mengelola sumber daya alam dengan memproses bahan galian untuk mendapatkan hasil akhir yang sangat berguna bagi umat manusia. Selain itu, di Indonesia mempunyai sumber daya yang berlimpah termasuk bahan galian pertambangan, sumber daya alam ini dikenal dengan mineral dan batubara (minerba). Mineral dan batubara yang terkandung dalam wilayah hukum pertambangan Indonesia merupakan kekayaan alam yang tidak dapat diperbaharui lagi, hal tersebut merupakan karunia Tuhan Yang Maha Esa yang mempunyai peranan sangat penting dalam memenuhi kepentingan dan kebutuhan orang banyak dan 
Jurnal Ilmu Sosial dan Pendidikan

http://ejournal.mandalanursa.org/index.php/JISIP/index

Terakreditasi Peringkat 5 (No. SK: 85/M/KPT/2020)

negara sangat bergantung terhadap pemanfaatan

hasil bumi tersebut sebagai modal pembangunan.

Oleh karena itu, pengelolaannya harus diatur dan dikuasai oleh negara agar dapat memberi nilai tambah secara nyata untuk perekonomian negara dalam usaha pencapaian kemakmuran dan kesejahteraan rakyat secara merata. Kekayaan alam yang terkandung di dalam bumi dan air yang biasa disebut dengan bahan-bahan galian, di mana seperti yang tertuang di dalam Pasal 33 ayat (3) UndangUndang Dasar 1945.

Amanat Undang-Undang Dasar 1945 ini merupakan landasan dalam pembangunan pertambangan dan energi untuk memanfaatkan potensi kekayaan sumber daya alam, mineral dan energi yang dimiliki secara optimal dan sebaik mungkin dalam mendukung pembangunan nasional yang berkelanjutan supaya dapat memberikan kesejahteraan dan kemakmuran rakyat.

Di zaman modernisasi seperti sekarang, setiap negara membangun perekonomian negaranya melalui sektor industri dengan cara mengelola sumber daya alam yang ada di negaranya dengan sebaik mungkin. Hal ini dilakukan agar dapat bersaing dengan negara lain dan memajukan perekonomian negaranya. Oleh karena itu, terdapat banyak perusahaan swasta ataupun privat yang mengelola hasil tambang untuk diproduksi.

Di dalam diskusi yang bertajuk "Kerugian Negara dari Unreporting Ekspor Batu bara Indonesia 2006-2016" yang diselenggarakan pada bulan November 2017 silam, menurut Indonesia Corruption Watch (ICW) Firdaus Ilyas, mengatakan adanya indikasi transaksi ekspor batu bara yang tidak dilaporkan hingga sebesar 27,06 miliar dolar AS (setara Rp. 365,3 triliun). Nilai ini tentu memiliki pengaruh terhadap pendapatan negara. Beliau juga mengatakan indikasi tidak dilaporkannya transaksi ekspor batubara tersebut disebabkan oleh sisi administratif negara adanya celah besar pendataan produksi batubara antara
Vol. 5. No. 1 Januari 2021

p-ISSN: 2598-9944 e- ISSN: 2656-6753

kementerian teknis dengan kementerian atau lembaga lainnya.

Pengelolaan pertambangan di berbagai daerah termasuk di Kalimantan Timur menunjukkan tanda-tanda yang mengkhawatirkan. Pada kenyataannya kini terdapat permasalahan atau isu yang harus diperhatikan oleh Pemerintah, yaitu masalah penambangan illegal. Penambangan illegal dilakukan tanpa izin, prosedur operasional, dan aturan dari pemerintah. Hal ini membuat kerugian pada negara karena mengeksploitasi sumber daya alam secara illegal, mendistribusikan, dan menjual hasil tambangnya secara illegal, sehingga terhindar dari pajak negara, hal ini lah yang menjadi masalah pertambangan masuk ke dalam hukum pidana khusus. Oleh karena itu, pemerintah harus menerapkan peraturan yang tegas terhadap pihak yang melakukan penambangan illegal.

Pemindahan kewenangan pengelolaan pertambangan dari pemerintah pusat ke pemerintah kabupaten atau kota mendorong kegiatan pertambangan batu bara berkembang pesat dan apabila tidak diikuti dengan kemampuan yang memadai dari aparat pemerintah daerah untuk melaksanakan tugasnya dengan baik dan mengawasi jalannya kegiatan penambangan tersebut dapat menyebabkan kegiatan pertambangan di beberapa daerah menjadi tidak terkendali, yang salah satu dampaknya adalah dalam bentuk kerusakan lahan bekas tambang.

Pertambangan batubara tidak hanya diusahakan oleh perusahaan pertambangan batubara yang memiliki izin, tetapi ternyata diusahakan pula oleh perusahaan pertambangan batubara tanpa izin, yang disebut PETI. Sebagaimana telah diketahui di atas bahwa negara mempunyai hak menguasai atas bumi, air dan kekayaan alam yang terkandung di dalamnya termasuk tambang. Berdasarkan hal tersebut, setiap orang yang akan melakukan pertambangan prosedurnya wajib meminta izin terlebih dahulu dari negara atau pemerintah. 
Jurnal Ilmu Sosial dan Pendidikan

http://ejournal.mandalanursa.org/index.php/JISIP/index

Terakreditasi Peringkat 5 (No. SK: 85/M/KPT/2020)

Menurut data illegal mining yang ada, angka data illegal mining di Provinsi Kalimantan Timur (Kaltim) meningkat, pada tahun 2016 kegiatan pertambangan illegal berada di 7 (tujuh) titik kordinat dengan perusahaan atau pelaku yang berbeda-beda, sedangkan pada tahun 2017 kegiatan pertambangan illegal berada di 16 (enam belas) titik kordinat dan perusahaan atau pelaku yang berbeda-beda juga.

Sedangkan ada 210 izin usaha pertambangan (IUP) batu bara "siluman" alias illegal diperkirakan ada di Kalimantan Timur. Hal ini merujuk selisih data antara Kementerian Energi dan Sumber Daya Alam (ESDM) dengan Pemprov Kaltim. Data dari kementerian per Desember 2017 silam menunjukkan, jumlah IUP di Kaltim ada sebanyak 1.194 izin. Sementara Dinas ESDM Kaltim mengklaim 1.404 IUP yang tercatat. IUP tersebut merujuk data yang diserahkan pemerintah kabupaten (pemkab) dan pemerintah kota (pemkot) di Kaltim pada 2016 lalu.

Di Kabupaten Kutai Kartanegara di Kecamatan Tenggarong kegiatan pertambangan illegal semakin marak, operasi mereka tidak lagi sembunyi-sembunyi. Pengerukan "emas hitam" bumi di Kalimantan Timur sudah secara terangterangan. Yang lebih parah, penambang melakukan pengangkutan di siang hari.

Bukan rahasia lagi, aktivitas penambang batu bara direkam dalam bentuk video dan foto yang memperlihatkan banyaknya dump truck pengangkut batubara melintas di siang hari.

Tindakan PETI tersebut tentu merupakan tindakan yang dapat dipidana, karena hal tersebut merupakan suatu pelanggaran terhadap aturan yang tertuang dalam berbagai peraturan perundang-undangan. Hal tersebut tidak hanya diatur di dalam Pasal 158 Undang-Undang Nomor 4 Tahun 2009 tentang Pertambangan Mineral dan Batu bara, tetapi hal tersebut juga diatur di dalam Pasal 55, Pasal 56 ayat (1) ke-1 Kitab Undang-Undang Hukum Pidana (KUHP), dan juga diatur dalam Pasal 109 jo. Pasal 116 Undang-Undang Nomor 32 Tahun 2009 tentang Lingkungan Hidup.
Vol. 5. No. 1 Januari 2021

p-ISSN: 2598-9944 e-ISSN: 2656-6753

Apabila terjadi kegiatan penambangan pelakunya tidak memiliki izin, maka perbuatannya merupakan tindak pidana yang diatur dalam Pasal 158 Undang-Undang Nomor 4 Tahun 2009 tentang Pertambangan Mineral dan Batu Bara. Namun tampaknya Kabupaten Kutai Kartanegara masih menjadi incaran para pengusaha nakal untuk meraup untung dengan menjadi penambang batu bara illegal.

Bagi mereka para pengusaha nakal yang melakukan penambangan dengan cara illegal dapat dikenakan sanksi pidana, denda dan pidana tambahan, yaitu perampasan barang yang digunakan dalam melakukan tindak pidana, perampasan keuntungan yang diperoleh dari tindak pidana serta kewajiban membayar biaya yang ada akibat tindak pidana tersebut sesuai yang diatur di dalam Pasal 158, Pasal 161 dan Pasal 164 Undang-Undang Nomor 4 Tahun 2009.

Pada dasarnya hukuman pidana yang dapat dijatuhkan hakim kepada terdakwa sifatnya hanya 2 (dua) macam, yaitu yang bersifat kumulatif (terdakwa dihukum dengan 2 (dua) hukuman pokok sekaligus yaitu pidana penjara dan pidana denda), sedangkan yang bersifat alternatif (hakim wajib memilih salah satu hukuman yaitu pidana badan atau pidana kurungan). Tindak pidana di bidang pertambangan tidak membedakan mana yang delik kejahatan dengan pelanggaran dan hukuman yang dijatuhkan terhadap pelakunya terdapat hukuman yang bersifat kumulatif dan alternatif. Pada hukuman yang bersifat kumulatif terdapat pada delik kejahataan yaitu Pasal 158, Pasal 159, Pasal 160 ayat (2), Pasal 161, dan Pasal 165 Undang-Undang Nomor 4 Tahun 2009 tentang Pertambangan Mineral dan Batu Bara. Sedangkan hukuman yang bersifat alternatif terdapat pada delik pelanggaran, yaitu Pasal 160 ayat (1) dan Pasal 162 Undang-Undang Nomor 4 Tahun 2009 tentang Mineral dan Batu Bara.

Pada dasarnya, kasus ini sudah marak terjadi, namun masyarakat yang ada di sekitarnya terlalu apatis dengan dampaknya tidak hanya merusak ekosistem, tetapi dapat 
Jurnal IImu Sosial dan Pendidikan

http://ejournal.mandalanursa.org/index.php/JISIP/index

Terakreditasi Peringkat 5 (No. SK: 85/M/KPT/2020)
Vol. 5. No. 1 Januari 2021

p-ISSN: 2598-9944 e- ISSN: 2656-6753 menyebakan longsor yang sering kali memakan korban jiwa. Ada beberapa faktor penyebab terjadinya PETI, seperti lemahnya pengawasan terhadap usaha pertambangan, lemahnya penegakan hukum, proses perizinan yang rumit dan memakan waktu yang lama, serta banyaknya praktik suap dan pungli yang menyebabkan retibusi dan pajak tidak sampai ke kas pemerintah.

Seperti contohnya pada kasus yang dibahas di dalam penelitian ini, pertambangan batubara tanpa izin yang dilakukan oleh Asep Tresnawan bersama saksi $H$. Nunu Kurnia Prawira, saksi Wang Suwandi (dilakukan penuntutan terpisah dari Asep Tresnawan). Pertambangan batu bara tanpa izin tersebut dilakukan oleh Asep Tresnawan selaku Manager Operasional yang terjadi Kalimantan Timur. Penyidik melakukan penyidikan terhadap kasus ini sejak tanggal 20 Mei 2014 sampai tanggal 8 Juni 2014 dan pada tanggal 13 Agustus 2015 Pengadilan Negeri Tenggarong Nomor 463/Pid.B/2014/PN.Trg menjatuhkan putusan bahwa Asep Tresnawan tidak terbukti secara sah dan tidak meyakinkan bersalah melakukan tindak pidana sebagaimana dalam dakwaan penuntut umum dan membebaskan Asep Tresnawan tersebut dari dakwaan. Sementara hasil Putusan Mahkamah Agung Nomor 153 K/PID.SUS/2016 menyatakan bahwa Asep Tresnawan terbukti secara sah dan meyakinkan bersalah melakukan tindak pidana sebagaimana dalam dakwaan jaksa penuntut umum pada Pengadilan Negeri Tenggarong dan karena perbuatannya terdakwa, maka terdakwa diadili dengan hukuman 3 (tiga) bulan pidana dan pidana denda sebesar Rp. 1.000.000.000,00 (satu miliar rupiah) karena telah melakukan perbuatan pertambangan tanpa izin.

Oleh karena itu, peran aparat penegak hukum sangat penting dalam melakukan penegakan hukum terhadap tindak pidana penambangan tanpa izin yang terjadi. Namun pada kenyataannya, upaya penegakan hukum terhadap kasus pertambangan batu bara illegal tampaknya tidak maksimal dalam memberikan tujuan pemidanaan, yaitu pemberikan efek jera kepada para pelaku dikarenakan jumlah pelaku tindak pidana pertambangan batu bara illegal masih saja marak di beberapa daerah di Indonesia, sebagai contohnya di kawasan Kabupaten Kutai Kartanegara.

Berdasarkan uraian latar belakang di atas, penulis ingin lebih banyak mengetahui tentang pertambangan batubara illegal dan bagaimanakah pemidanaan terhadap tindak pidana tersebut berdasarkan hukum postitif yang berlaku di Indonesia. Oleh karena itu, penulis tertarik untuk menulis skripsi dengan judul: "Analisis Pemidanaan Hukuman Terhadap Tindak Pidana Pertambangan Batu Bara Tanpa Izin Usaha Pertambangan di Kutai (Studi Kasus Putusan Perkara Pidana No. 153 K/PID.SUS/2016)".

\section{Pokok Masalah}

Dari uraian mengenai latar belakang di atas, maka di dalam pokok permasalahan ini penulis mengajukan pertanyaan yang berkaitan dengan tindak pidana pertambangan batu bara tanpa izin. Penulis merumuskan masalah sebagai berikut:

Bagaimanakah mekanisme kegiatan usaha pertambangan dalam pertambangan PT Utama Kawan Energi apabila dilihat dari Undang-Undang Nomor 4 Tahun 2009 tentang Pertambangan dan Mineral Batu Bara?

Apakah pemidanaan dalam Putusan Perkara Nomor 153 K/PID.SUS/2016 telah sesuai dengan Undang-Undang Nomor 4 Tahun 2009 tentang Mineral dan Batu Bara?

\section{Tujuan Penulisan}

Tujuan dari penulisan ini adalah sebagai berikut:

1. Untuk mengetahui bagaimana mekanisme pertambangan menurut Undang-Undang Nomor 4 Tahun 2009 tentang Mineral dan Batu Bara.

2. Untuk mengetahui Putusan Perkara Nomor 153K/PID.SUS/2016 pemidanaannya telah sesuai dengan Undang-Undang Nomor 4 Tahun 2009 tentang Mineral dan Batu Bara atau belum. 


\section{METODE PENELITIAN}

Penelitian ini menggunakan metode preskriptif yuridis normatif yakni merupakan metode penelitian hukum kepustakaan atau penelitian hukum yang pelaksanaannya dilakukan dengan meneliti bahan pustaka yang ada. Dengan metode ini penulis akan melakukan penelitian dengan melakukan identifikasi pokokpokok permasalahan yang hendak dibahas secara tuntas dengan norma hukum yang terdapat dalam peraturan perundang-undangan terkait dan jika memerlukan wawancara maka akan juga dilakukan wawancara kepada informan dan narasumber terkait.

Mekanisme Usaha Pertambangan dalam Kegiatan Pertambangan PT Utama Kawan Energi Tidak Sesuai Menurut Undang-Undang Nomor 4 Tahun 2009 tentang Pertambangan dan Mineral Batu Bara

Siapapun yang akan melakukan pertambangan batu bara dianggap sudah mengetahui mekanisme yang harus dilalui untuk melakukan pertambangan batu bara,

\section{HASIL DAN PEMBAHASAN}

\section{a. Pengertian Pertambangan}

Pertambangan merupakan suatu aktivitas penggalian, pembongkaran serta pengangkutan suatu endapan mineral yang terkandung dalam suatu wilayah dengan melalui beberapa tahapan kegiatan secara efektif dan ekonomis dengan menggunakan peralatan mekanis serta beberapa peralatan sesuai dengan perkembangan teknologi saat ini.

Untuk definisi dari hukum pertambangan itupun sendiri, Salim HS. berpendapat:

"Hukum pertambangan adalah keseluruhan kaidah hukum yang mengatur kewenangan negara dalam pengelolaan bahan galian (tambang) dan mengatur hubungan hukum antara negara dengan orang dan atau badan hukum dalam pengelolaan dan pemanfaatan bahan (tambang).

Jurnal Ilmu Sosial dan Pendidikan

\section{b. Asas-asas Pertambangan}

Di dalam Pasal 2 Undang-Undang Nomor 4 Tahun 2009 tentang Pertambangan Mineral dan Batu Bara tertuang asas-asas hukum pertambangan ada empat (4) macam, yaitu sebagai berikut:

- Manfaat, keadilan dan keseimbangan.

- Keberpihakan kepada kepentingan bangsa.

- Partisipatif, transparansi dan akuntabilitas

- Berkelanjutan dan berwawasan lingkungan.

c. Pengertian Usaha Pertambangan

Sejak Undang-Undang Nomor 4 Tahun 2009 tentang Pertambangan Mineral dan Batu Bara diberlakukan, legalitas pengusahaan pertambangan hanya dalam satu bentuk, yaitu izin. Menurut pendapat E. Utrecht, bila pembuat peraturan umumnya tidak melarang suatu perbuatan, tetapi masih juga memperkenankannya asal saja diadakan secara yang ditentukan untuk masing-masing hal konkret, keputusan adminstrasi negara yang memperkenankan hal tersebut bersifat izin (vergunning). Mengenai definisi izin, Van der pot berpendapat bahwa izin merupakan keputusan yang memperkenankan dilakukannya perbuatan yang pada prinsipnya tidak dilarang oleh pembuat aturan.

\section{d. Pengertian Pemidanaan}

Pemidanaan bisa diartikan sebagai tahap penetapan sanksi dan juga tahap pemberian sanksi dalam hukum pidana. Kata "pidana" pada umumnya diartikan sebagai hukum, sedangkan "pemidanaan" diartikan sebagai penghukuman. Pemidanaan merupakan bagian penting dalam hukum pidana, karena merupakan puncak dari seluruh proses mempertanggungjawabkan seseorang yang telah bersalah melakukan tindak pidana. Jika kesalahan dipahami sebagai "dapat dicela", maka di sini pemidanaan merupakan "perwujudan dari celaan" tersebut.

Jika adanya kegagalan dalam pencapaian konsistensi dalam pendekatan terhadap pemidanaan, maka hal ini akan menimbulkan rasa injustice. Karena seorang pelaku tindak pidana mungkin akan memperoleh pidana yang lebih berat dari yang lain, dan sebaliknya. 
Demikian pula pandangan masyarakat terhadap persamaan hak dalam peradilan akan terganggu apabila terjadi fluctuation in sentencing.

Menurut W.A. Bonger, mengartikan pemidanaan adalah sebagai berikut:
"Menghukum adalah mengenakan
penderitaan. Menghukum sama artinya dengan "celaan kesusilaan" yang timbul terhadap tindak pidana itu, yang juga merupakan penderitaan. Hukuman pada hakikatnya merupakan perbuatan yang dilakukan oleh masyarakat (dalam hal ini negara) dengan sadar. Hukuman tidak keluar dari satu atau beberapa orang, tapi harus suatu kelompok, suatu kolektivitas yang berbuat dengan sadar dan menurut perhitungan akal. Jadi "unsur pokok" baru hukuman, ialah "tentangan yang dinyatakan oleh kolektivitas dengan sadar.

1. Mekanisme Usaha Pertambangan dalam Kegiatan Pertambangan PT Utama Kawan Energi Tidak Sesuai Menurut Undang-Undang Nomor 4 Tahun 2009 tentang Pertambangan dan Mineral Batu Bara

Siapapun yang akan melakukan pertambangan batu bara dianggap sudah mengetahui mekanisme yang harus dilalui untuk melakukan pertambangan batu bara, mulai dari mengurus izin usaha pertambangan sampai nanti pada proses reklamasi. Seseorang yang berprofesi di bidang pertambangan yang melakukan tindak pidana pertambangan tanpa izin tentunya dalam tatanan hukum positif yang berlaku di Indonesia merupakan sebuah perbuatan yang sangat tercela yang dilarang oleh Undang-Undang Nomor 4 Tahun 2009, terlebih lagi tindakan tersebut sedang gencar-gencarnya menjadi sorotan Pemerintah.

Apabila ada satu saja mekanisme yang dilewatkan tentu saja ada akibat hukumnya. Seperti pada kasus Perkara Nomor 153 K/Pid.Sus/2016 ini, sebagaimana yang telah diketahui bahwa izin usaha pertambangan tersebut telah mati pada tanggal 11 April 2014, namun kegiatan pertambangan tersebut tetap diperintahkan diteruskan sampai sebulan lamannya.

Tentu saja perbuatan tersebut menyalahi mekanisme dalam usaha pertambangan menurut Undang-Undang Nomor 4 Tahun 2009. Di mana hal tersebut telah dijelaskan di dalam Pasal 1 angka 7 yang mana di situ disebutkan bahwa "Izin Usaha Pertambangan adalah izin untuk melaksanakan usaha pertambangan." Tentu saja dengan tidak memiliki Izin Usaha Pertambangan yang aktif ini berarti hal itu telah melanggar ketentuan dan syarat untuk melakukan sebuah usaha pertambangan. Ketentuan tersebut tentu saja sudah diatur di dalam Undang-Undang Nomor 4 Tahun 2009 di dalam Pasal 158, di mana Pasal tersebut berbunyi:

"Setiap orang yang melakukan usaha penambangan tanpa IUP, IPR atau IUPK sebagaimana dimaksud dalam Pasal 37, Pasal 40 ayat (3), Pasa; 48, Pasal 67 ayat (1), Pasal 74 ayat (1) atau ayat (5) dipidana dengan pidana penjara paling lama 10 (sepuluh) tahun dan denda paling banyak Rp. 10.000.000.000,00 (sepuluh miliar rupiah).”.

Mekanisme usaha pertambangan sebenarnya sudah dijelaskan dengan jelas pada Undang-Undang Nomor 4 Tahun 2009 yaitu pertama-tama harus memiliki izin usaha pertambangan, yang mana izin usaha pertambangan terbagi menjadi dua, yang pertama adalah izin usaha ekplorasi, dan yang ke dua adalah izin usaha pertambangan operasi produksi. Apabila ingin melakukan kegiatan usaha pertambangan, itu harus memiliki kedua izin usaha pertambangan tersebut, jika salah satu izin usaha pertambangan tersebut tidak ada, itu berarti telah menyalahi aturan mekanisme untuk melakukan kegiatan pertambangan.

Menurut penulis, seperti apa yang disebutkan di atas terlihat jelas adanya pelanggaran terhadap mekanisme usaha pertambangan, yang mana ia tidak memiliki lagi izin usaha pertambangan operasi produksi dikarenakan izin tersebut telah habis masa berlakunya sejak tangggal 11 April 2014, seharusnya apabila mengacu kepada peraturan 
Jurnal Ilmu Sosial dan Pendidikan

http://ejournal.mandalanursa.org/index.php/JISIP/index

Terakreditasi Peringkat 5 (No. SK: 85/M/KPT/2020)

perundang-undangan yang ada, pemegang izin usaha pertambangan tersebut (CV. Bunga Bone) harus melakukan perpanjangan izin usaha pertambangan produksi terlebih dahulu sebelum melakukan kegiatan pertambangan lagi. Yang nantinya, izin usaha pertambangan yang diperpanjang itu akan dikeluarkan oleh Gubernur seperti yang diatur dalam Pasal 37 Undang-Undang Nomor 4 Tahun 2009 tentang Pertambangan Mineral dan Batu Bara.

Guna dikeluarkannya lagi izin usaha pertambangan operasi produksi adalah supaya pemegang izin usaha pertambangan tersebut mempunyai hak untuk melakukan kegiatan produksi pertambangan. Dan selama pengurusan izin tersebut tidak dilakukan, maka seperti yang diatur di dalam Pasal 123 Undang-Undang Nomor 4 Tahun 2009, pemegang IUP tersebut wajib menyerahkan seluruh data yang diperoleh dari hasil eksplorasi dan operasi produksi kepada menteri/gubernur atau bupati/walikota sesuai dengan kewenangannya. Otomatis dengan pengaturan tersebut terlihat jelas tidak boleh lagi adanya kegiatan pertambangan di wilayah IUP tersebut.

Izin usaha pertambangan operasi produksi itu sendiri memiliki jangka waktu yang lebih lama daripada izin usaha pertambangan eksplorasi yang hanya memiliki batasan waktu maksimal 7 (tujuh) tahun, sedangkan izin usaha pertambangan operasi produksi ini memiliki jangka waktu paling lama 20 (dua puluh) tahun dan dapat diperpanjang 2 (dua) kali dan masingmasing perpanjangan itu 10 (sepuluh) tahun. Hal tersebut telah tercantum di dalam Pasal 47 ayat (5) Undang-Undang Nomor 4 Tahun 2009 tentang Pertambangan Mineral dan Batu Bara.

Dan apabila izin usaha pertambangan operasi produksi tersebut tidak diperpanjang itu artinya pemegang izin usaha pertambangan tersebut tidak mempunyai kewajiban maupun hak untuk melakukan kegiatan pertambangan. Yang dimaksud disini hak sebagai pemegang izin usaha pertambangan itu adalah salah satunya adalah dapat melakukan sebagian atau seluruh tahapan usaha pertambangan, baik
Vol. 5. No. 1 Januari 2021

p-ISSN: 2598-9944 e- ISSN: 2656-6753

kegiatan eksplorasi maupun kegiatan operasi produksi dan hak tersebut dijamin seperti ketentuan peraturan perundang-undangan. Dan tentu saja apabila tidak memiliki izin usaha pertambangan, maka tidak berhak untuk melakukan sebagian ataupun keseluruhan tahapan usaha pertambangan.

Menurut pendapat penulis, seperti yang tercantum dengan jelas mengenai hal-hal yang menyebabkan berahkir izin usaha pertambangan di dalam Pasal 117 Undang-Undang Nomor 4 Tahun 2009 tentang Pertambangan Mineral dan Batu Bara, yang salah satunya dikarenakan telah habisnya masa berlaku izin usaha pertambangan. Sejak dinyatakan izin usaha pertambangan tersebut berahkir, seharusnya pemegang izin usaha pertambangan tersebut harus menyerahkan seluruh data yang diperoleh kepada menteri, gubernur, bupati/walikota sesuai dengan wewenangnya.

Maka, apapun kegiatan pertambangan yang dilakukan wilayah izin usaha pertambangan yang telah habis masa berlakunya dengan tanpa dilakukan perpanjangan kembali izin usaha pertambangan operasi produksi tersebut, merupakan sebuah perbuatan yang sangat tercela karena dengan melakukan tindakan pertambangan tanpa izin tidak sesuai dengan mekanisme yang benar seperti mengurus perizinan itu berarti tidak adanya pembayaran pajak kepada negara dan hal itu sangat merugikan negara, terlebih lagi hal tersebut juga sudah jelas ada sanksinya untuk para pelaku pertambangan tanpa izin usaha pertambangan, baik sanksi pidana ataupun sanksi administrasi seperti yang diatur dalam Pasal 158 UndangUndang Nomor 4 Tahun 2009 tentang Pertambangan Mineral dan Batu Bara.

Berdasarkan uraian di atas, maka dapat ditarik simpulan bahwa memang betul Asep Tresnawan telah menyalahi mekanisme usaha pertambangan yang ada di dalam peraturan perundang-undangan. Perbuatan yang dilakukan oleh Asep Tresnawan itu sangat bertentangan dengan Undang-Undang Nomor 4 Tahun 2009, padahal di dalam Undang-Undang Nomor 4 
Jurnal IImu Sosial dan Pendidikan

http://ejournal.mandalanursa.org/index.php/JISIP/index

Terakreditasi Peringkat 5 (No. SK: 85/M/KPT/2020)
Vol. 5. No. 1 Januari 2021

p-ISSN: 2598-9944 e- ISSN: 2656-6753
Tahun 2009 sudah tidak ada celah untuk pelaku illegal mining, tetapi Asep Tresnawan tetap saja melakukan perbuatan tersebut. Yang mana awal dari kesalahan Asep Tresnawan itu disebabkan ia tidak mengikuti aturan yang ada, dengan tidak memperpanjang atau setidaknya menghentikan sementara kegiatan pertambangan sampai masalah perizinan yang telah habis masa berlakunya itu diperpanjang, yang jelas-jelas sebagai manager operasional sudah ia ketahui aturan tersebut dan tentu akan ada pemberat baginya jika ia melakukan hal tersebut.

Putusan Perkara Nomor 153 K/PID.SUS/2016 Sesuai dengan Undang-Undang Nomor 4 Tahun 2009 tentang Mineral dan Batu Bara.

\section{Putusan Perkara Nomor 153 K/PID.SUS/2016 Sesuai dengan Undang-Undang Nomor 4 Tahun 2009 tentang Mineral dan Batu Bara}

Dalam Putusan Perkara Nomor 153 K/PID.SUS/2016 dinilai tidak sesuai dengan Pasal 158 Undang-Undang Nomor 4 Tahun 2009 karena dalam menjatuhkan putusan Majelis Hakim dianggap terlalu jauh dari ancaman pidana penjara maksimal yaitu 10 (sepuluh) tahun dan denda paling banyak Rp. 10.000.000.000 (sepuluh miliar rupiah) Karena dengan jelas Asep Tresnawan mengetahui bahwa izin usaha pertambangan tersebut akan mati pada tanggal 11 April 2014, namun ia tetap menyuruh serta turut meneruskan kegiatan pertambangan tersebut.

Seperti mana yang diatur dalam UndangUndang Nomor 4 Tahun 2009 konsekuensi dari kegiatan yang ia lakukan itu memenuhi unsurunsur tindak pidana pertambangan tanpa izin, yaitu adanya unsur setiap orang dan unsur yang melakukan usaha penambangan tanpa IUP, IPR atau IUPK. Tentu saja setiap perbuatan tindak pidana akan ada sanksi yang mengikuti, dalam kasus ini, Asep Tresnawan dijerat dengan Pasal 158 Undang-Undang Nomor 4 Tahun 2009 jo. Pasal 55 ayat (1) Kitab Undang-Undang Hukum Pidana. Yang mana dalam Pasal 158 UndangUndang Nomor 4 Tahun 2009 itu memuat pidana penjara maksimal 10 (sepuluh) tahun dan denda paling banyak Rp. 10.000.000.000,00 (sepuluh miliar rupiah).

Sedangkan di dalam Pasal 55 Kitab Undang-Undang Hukum Pidana dirumuskan sebagai berikut:

Dihukum sebagai orang yang melakukan peristiwa pidana:

Orang yang melakukan, yang menyuruh melakukan, atau turut melakukan perbuatan itu;

Orang yang dengan pemberian, perjanjian, salah memakai kekuasaan atau pengaruh, kekerasan, ancaman atau tipu daya atau dengan memberi kesempatan, daya upaya atau keterangan, sengaja membujuk untuk melakukan sesuatu perbuatan.

Tentang orang-orang yang tersebut dalam sub $b$ itu yang boleh dipertanggungjawabkan kepadanya hanyalah perbuatan yang dengan sengaja dibujuk oleh mereka itu, serta dengan akibatnya.

Penulis sependapat dengan Majelis Hakim, perbuatan pertambangan tanpa izin itu seharusnya di jatuhkan hukuman yang setimpal terlebih lagi Asep Tresnawan merupakan pihak yang menyuruh serta turut melakukan, dilihat berdasarkan alasan-alasan Mahkamah Agung pada tingkat kasasi Nomor: 153 K/Pid.Sus/2016, halaman 28 yang menyatakan bahwa "karena permohonan kasasi dari Pemohon Kasasi/Penuntut Umum dikabulkan, maka Terdakwa yang dinyatakan bersalah, harus di pidana setimpal dengan perbuatan tersebut".

Dapat dilihat bahwa Asep Tresnawan merupakan orang yang menyuruh melakukan dan turut melakukan perbuatan tindak pidana pertambangan tanpa izin dan tentu saja perbuatan Asep Tresnawan sangat merugikan negara karena dengan tidak perpanjangnya izin tersebut dan Asep Tresnawan masih terusmenerus melakukan kegiatan pertambangan tanpa membayar pajak kepada negara. Bukan hanya sekedar merusak lingkungan, jika perbuatan tersebut tidak dijatuhkan hukuman yang menjerakan, kegiatan pertambangan tanpa izin tersebut dapat merusak sumber daya alam juga. Menurut penulis, hal-hal tersebut 
Jurnal Ilmu Sosial dan Pendidikan

http://ejournal.mandalanursa.org/index.php/JISIP/index

Terakreditasi Peringkat 5 (No. SK: 85/M/KPT/2020)
Vol. 5. No. 1 Januari 2021

p-ISSN: 2598-9944 e- ISSN: 2656-6753 merupakan salah satu keadaan yang memberatkan, yang mana hal tersebut tidak disebutkan sebagai faktor-faktor keadaan yang memberatkan oleh Majelis Hakim. Padahal hal tersebut sangat berpengaruh, karena Asep Tresnawan bukan hanya merusak lingkungan tetapi merugikan orang banyak termasuk negara.

Sementara Majelis Hakim dalam argumentasinya, pada Perkara Nomor 153 K/Pid.Sus/2016, halaman 29, hanya menyatakan bahwa "Keadaan yang memberatkan: Perbuatan terdakwa dapat menyebabkan rusaknya lingkungan dan Perbuatan tersebut dilakukan oleh terdakwa pada saat pemerintah sedang gencar-gencarnya memberantas kejahatan illegal mining."

Majelis Hakim dianggap terlalu rendah di dalam penjatuhan putusannya, pada Perkara Nomor 153 K/Pid.Sus/2016, halaman 29, yang menyatakan bahwa: "Menjatuhkan pidana terhadap Terdakwa Asep Tresnawan bin Nang Wangun dengan pidana penjara selama 3 (tiga) bulan dan denda sebesar Rp1.000.000.000,00 (satu miliar rupiah) dengan ketentuan apabila denda tersebut tidak dibayarkan maka diganti dengan pidana kurungan selama 6 (enam) bulan." Putusan Mahkamah Agung No. 153 K/PID.SUS/2016 dianggap tidak sesuai dengan tujuan pemidanaan pembalasan (absolute) karena Majelis Hakim menjatuhkan hukuman pidana penjara selama 3 (tiga) bulan dan denda sebesar Rp1.000.000.000,00 (satu miliar rupiah) dengan ketentuan apabila denda tersebut tidak dibayarkan maka diganti dengan pidana kurungan selama 6 (enam) bulan. Sementara terdakwa telah menjalani penahanan Rumah Tahanan Negara (rutan) selama 7 (tujuh) bulan, dan putusan pidana penjara tersebut akan dikurangi $1 / 3$ dari masa penahanan yang telah dijalani selama di Rumah Tahanan Negara (RUTAN), secara tidak langsung masa penghukuman terdakwa hanya sekitar satu (1) bulan lima belas (15) hari. Apabila dilihat Pasal 158 Undang-Undang Nomor 4 Tahun 2009, tentu saja penghukuman tersebut sangat jauh dari batas maksimal pemidanaan tindak pidana pertambangan tanpa izin. Di dalam pemberat pun tidak disebutkan perbuatan Asep Tresnawanpun bukan hanya merusak lingkungan namun juga dapat merusak sumber daya alam.

Sebelum dibawa ke Mahkamah Agung, Pengadilan Negeri Tenggarong pun malah menjatuhi putusan bebas. Putusan Mahkamah Agung pun terkesan tidak memberikan efek jera kepada pelaku tindak pidana, karena penjatuhan hukuman tesebut sangat jauh dari batas maksimal. Tentu saja hal tersebut dapat membangun image bahwa tindakan pertambangan tanpa izin adalah sesuatu hal yang akan dijatuhi hukuman begitu ringan, sehingga tidak memberikan image mengerikan agar tidak ada pelaku tindak pidana penambangan illegal lainnya.

Dengan begitu menurut pendapat penulis dikatakan tidak sesuai dengan tujuan pemidanaan pembalasan maupun teori tujuan pemidananaan pun tidak tercapai. Menurut pendapat penulis teori tujuan pemidanaan gabungan yang serasa lebih cocok diberikan bagi para pelaku tindak pidana pertambangan tanpa izin. Teori gabungan merupakan perpaduan teori pembalasan dan teori tujuan.

Dengan adanya teori pemidanaan gabungan itu bukan hanya untuk pembalasan atas perbuatan masa lalu saja, namun juga untuk pencegahan dimasa yang akan datang. Pemidanaan itu harus dapat memberikan kepuasan bagi hakim, pelaku tersebut maupun bagi masyarakat. Dengan dimunculkan teori pemidanaan gabungan ini, maka akan terciptalah unsur pembalasan dan prevensi yang seimbang, antara pidana yang dijatuhkan dengan kejahatan yang telah dilakukan dan pencegahan terjadinya pengulangan tindak pidana dengan memberikan efek jera kepada pelaku perbuatan tersebut dan masyarakat lain.

Seharusnya majelis hakim setidaknya memberikan hukuman yang lebih tinggi, atau setidaknya mengabulkan tuntutan jaksa penuntut umum, yang menuntut hukuman pidana satu tahun enam bulan (1 tahun 6 bulan). Putusan 
Jurnal Ilmu Sosial dan Pendidikan

http://ejournal.mandalanursa.org/index.php/JISIP/index

Terakreditasi Peringkat 5 (No. SK: 85/M/KPT/2020)
Vol. 5. No. 1 Januari 2021

p-ISSN: 2598-9944 e- ISSN: 2656-6753
Hukuman majelis hakim terkesan berat sebelah. Dan seharusnya di dalam bidang pertambangan pun menerapkan pengaturan pemidanaan dengan batasan-batasan seperti contoh baiknya di dalam Undang-Undang Nomor 35 Tahun 2009 tentang Narkotika, yang mana di dalam undang-undang tersebut mencantumkan batasan batasan seperti;

Apabila seseorang yang tanpa hak menanam, memelihara, menyimpan naroktika dalam bentuk tanaman jika beratnya lebih dari 1 (satu) kilogram, pelaku pidana tersebut dapat dipidana penjara seumur hidup atau paling singkat 5 (lima) tahun dan paling lama 20 (dua puluh) tahun dan pidana denda maksimum ditambah $1 / 3$ (sepertiga), hal tersebut diatur dalam pasal 111 Undang-undang Nomor 35 Tahun 2009 tentang Narkotika.

Apabila seseorang yang tanpa hak menyimpan, menguasai atau menyediakan narkotika golongan I bukan tanaman, jika beratnya melebihi 5 (lima) gram, pelaku tersebut dapat dipidana penjara seumur hidup atau paling singkat 5 (lima) tahun dan paling lama 20 (dua puluh) tahun dan pidana denda maksimum ditambah $1 / 3$ (sepertiga), hal tersebut diatur dalam pasal 112 Undang-undang Nomor 35 Tahun 2009 tentang Narkotika.

Apabila seseorang yang tanpa hak memproduksi, mengimpor, mengekspor atau menyalurkan narkotika golongan I, jika dalam bentuk tanaman beratnya melebihi 1 (satu) kilogram atau dalam bentuk bukan tanaman beratnya lebih dari 5 (lima) gram pelaku dapat dipidana dengan pidana mati, pidana penjara seumur hidup atau paling singkat 5 (lima) tahun dan paling lama 20 (dua puluh) tahun dan pidana denda maksimum sditambah 1/3 (sepertiga), hal tersebut diatur dalam Pasal 113 Undang-Undang Nomor 35 Tahun 2009 tentang Narkotika.

Apabila seseorang yang tanpa hak menawarkan untuk dijual, menjual, membeli, menerima narkotika golongan I, jika dalam bentuk tanaman beratnya melebihi 1 (satu) kilogram atau dalam bentuk bukan tanaman beratnya 5 (lima) gram, pelaku akan dipidana dengan pidana mati, pidana penjara seumur hidup, atau pidana penjara paling singkat 6 (enam) tahun dan paling lama 20 (dua puluh) tahun dan pidana denda maksimum ditambah $1 / 3$ (sepertiga), hal tersebut diatur dalam Pasal 114 Undang-Undang Nomor 35 Tahun 2009 tentang Narkotika.

Dan lain lain. Namun, sangat disayangkan dikarenakan tidak adanya batasanbatasan yang jelas untuk mengtakar keseluruhan kerugian yang ditimbulkan akibat tindakan pertambangan tanpa izin tersebut, maka sering kali dijatuhkan putusan yang terkesan tidak adil bagi masyarakat. Apabila setiap kasus pertambangan tanpa izin seperti yang dilakukan oleh Asep Tresnawan diberikan putusan hukuman seringan itu apalagi sampai menjatuhkan putusan bebas, tentu saja tujuan pemidanaan tidak akan tercapai. Yang mana tujuan pemidanaan adalah untuk memberikan efek jera. Dan apabila penjatuhan hukuman bagi para pelaku tindak pidana pertambangan tanpa izin seringan itu dibiarkan terus menerus, maka akan mengakibatkan dianggap bahwa perbuatan tersebut akan menguntungkan, karena hasil keuntungan yang mereka dapatkan dari melakukan pertambangan tanpa izin lebih banyak ketimbang masa hukuman yang akan mereka jalani di penjara serta denda administrasinya. Tentu saja hal tersebut akan membahayakan bagi perekonomian negara dan keberlangsungan lingkungan negara serta sumber daya alam negara.

\section{KESIMPULAN}

Mekanisme di PT Utama Kawan Energi dalam kegiatan usaha pertambangan, tidak sesuai dengan pengaturan di dalam UndangUndang No 4 Tahun 2009 tentang Mineral dan Batu Bara, karena PT Utama Kawan Energi di dalam mekanisme izin, yang sudah jelas matinya izin usaha pertambangan produksi namun PT Utama Kawan Energi tidak menghentikan kegiatan pertambangan seperti yang diatur di dalam Undang-Undang No 4 Tahun 2009 tentang Mineral dan Batu Bara. PT Utama Kawan Energi juga tidak melakukan 
Jurnal Ilmu Sosial dan Pendidikan

http://ejournal.mandalanursa.org/index.php/JISIP/index

Terakreditasi Peringkat 5 (No. SK: 85/M/KPT/2020)
Vol. 5. No. 1 Januari 2021

p-ISSN: 2598-9944 e- ISSN: 2656-6753 perpanjangan izin, sehingga PT Utama Kawan Energi dalam mekanisme usaha pertambangan tidak sesuai dengan Undang-Undang No 4 Tahun 2009 tentang Mineral dan Batu Bara. Sementara Pemidanaan dalam putusan Nomor 153 K/Pid.Sus/2016 telah sesuai dengan Undang-Undang No 4 Tahun 2009, namun majelis hakim hanya menghukum 3 (tiga) bulan penjara dan denda sebesar Rp.1.000.000.000,00 (satu miliar rupiah) seharusnya berdasarkan teori tujuan pemidanaan absolute, majelis hakim harus menghukum maksimal terhadap perbuatan terdakwa yang membuat kerugian lingkungan dan pajak negara yaitu pidana penjara 10 (sepuluh) tahun dan denda maksimal sebesar Rp. 10.000.000.000 (sepuluh miliar rupiah), sementara dalam menjatuhkan sanksi pidana, Majelis Hakim menjatuhkan hukuman terlalu singkat. Sehingga tidak tercapainya tujuan dari teori pemidanaan absolute.

\section{SARAN}

Para penambang batu bara harus menaati mekanisme yang ada di dalam perundangundangan seperti, membuat izin usaha pertambangan, untuk mendapatkan hak dan kewajiban sebagai pemegang izin usaha pertambangan serta harus memperhatikan kapan izin usaha pertambangan tersebut dapat dikatakan berahkir sehingga dapat melakukan perpanjangan izin usaha pertambangan tersebut, jadi tidak akan merugikan negara dan tidak merusak lingkungan serta sumber daya alam.

Hakim dalam memberikan putusan sanksi harus sesuai dengan teori tujuan pemidanaan absolute terutama untuk tindak pidana pertambangan tanpa izin. Serta diciptakannya batasan-batasan dalam penjatuhan hukuman untuk tindak pidana pertambangan tanpa izin seperti contohnya dalam pengaturan pemidanaan mengenai Narkotika, disana adanya batasan batasan yang jelas sehingga tidak akan adanya hukuman yang semena-mena. Supaya dapat tercapainya tujuan pemidanaan serta teori pemidanaan pembalasan, agar terpenuhinya suatu keadilan dan ketertiban serta juga adanya pencegahan di masa yang akan datang agar tidak adanya pengulangan tindak pidana pertambangan tanpa izin

\section{DAFTAR PUSTAKA}

Bonger, W.A. Pengantar tentang Kriminologi, Jakarta: PT. Pembangunan, 1982

Himawan, Adhitya. ICW Sebut Ada Ekspor Batu Bara Ilegal 27,06 Miliar Dolar $A S,<\underline{\text { https://www.suara.com/bisnis/201 }}$ 7/11/20/130347/icw-sebut-ada-eksporbatubara-ilegal-2706-miliar-dolar-as,> diakses pada tanggal 31 Desember 2020 pukul 21.39.

Huda, Chairul. Dari Tiada Pidana Tanpa Kesalahan Menuju Kepada Tiada Pertanggungjawaban Pidana Tanpa Kealahan. Tinjauan Kritis Terhadap Teori Pemisahan Tindak Pidana dan Pertanggungjawaban Pidana, Jakarta: Kencana Prenada Media, 2006

inas Energi dan Sumberdaya Energi, Data Illegal Mining 2016 dan 2017 dengan Kordinat, Kalimantan Timur, 2018.

Koran Kaltim, "Tambang Ilegal di Tenggarong Seberang Makin Marak", <https://www.korankaltim.com/headli ne/read/11973/tambang-ilegal-ditenggarong-seberang-makin-marak>, diakeses pada tanggal 5 Januari 2021 23.55 .

Muladi, Kapita Selekta Sistem Peradilan Pidana, Semarang: Badan Penerbit Universitas Diponegoro, 1995.

Pudyatmoko, Y. Sri. Perizinan Problem dan Upaya Pembenahan, Jakarta : PT Grasindo, 2009.

Redaksi M1, Waspada Izin Pertambangan Bodong, Diduga 210 Usaha, <https://fajar.co.id/2018/05/01/waspad a-izin-pertambangan-bodong-diduga210-usaha/ $>$, diakses pada tanggal 5 Januari 2021 pukul 23.40.

Salim HS., Hukum Pertambangan di Indonesia, Jakarta: Rajawali Pers, 2012. 
Jurnal Ilmu Sosial dan Pendidikan

http://ejournal.mandalanursa.org/index.php/JISIP/index

Terakreditasi Peringkat 5 (No. SK: 85/M/KPT/2020)
Vol. 5. No. 1 Januari 2021

p-ISSN: 2598-9944 e- ISSN: 2656-6753

Supramono, Gatot. Hukum Pertambangan Mineral dan Batu Bara di Indonesia, Jakarta: Rineka Cipta, 2012.

Utrecht, E. Pengantar dalam Hukum Indonesia, Djakarta: Ichtiar,1957. 